Article

\title{
Purification of Bioactive Peptide with Antimicrobial Properties Produced by Saccharomyces cerevisiae
}

\author{
Shayma Thyab Gddoa Al-sahlany ${ }^{1}$, Ammar B. Altemimi ${ }^{1}{ }^{(}$, Alaa Jabbar Abd Al-Manhel ${ }^{1}(\mathbb{D}$, \\ Alaa Kareem Niamah ${ }^{1, * \mathbb{D}}$, Naoufal Lakhssassi ${ }^{2}$ and Salam A. Ibrahim ${ }^{3}$ \\ 1 Department of Food Science, College of Agriculture, University of Basrah, Basrah 61004, Iraq; \\ alsahlany.shayma@gmail.com (S.T.G.A.-s.); ammaragr@siu.edu (A.B.A.); \\ alaafood_13@yahoo.com (A.J.A.A.-M.) \\ 2 Department of Plant Soil and Agricultural Systems, Agriculture College, Southern Illinois University, \\ Carbondale, IL 62901, USA; naoufal.lakhssassi@siu.edu \\ 3 Food and Nutritional Science Program, North Carolina A \& T State University, Greensboro, NC 27411, USA; \\ ibrah001@ncat.edu \\ * Correspondence: ammaragr@siu.edu; Tel.: +964-773-564-0090
}

Received: 7 February 2020; Accepted: 9 March 2020; Published: 11 March 2020

\begin{abstract}
A variety of organisms produce bioactive peptides that express inhibition activity against other organisms. Saccharomyces cerevisiae is considered the best example of a unicellular organism that is useful for studying peptide production. In this study, an antibacterial peptide was produced and isolated from Saccharomyces cerevisiae (Baker's yeast) by an ultrafiltration process (two membranes with cut-offs of 2 and $10 \mathrm{kDa}$ ) and purified using the ÄKTA Pure 25 system. Antibacterial peptide activity was characterized and examined against four bacterial strains including Gram-positive and Gram-negative bacteria. The optimum condition for yeast growth and antibacterial peptide production against both Escherichia. coli and Klebsiella aerogenes was $25-30^{\circ} \mathrm{C}$ within a $48 \mathrm{~h}$ period. The isolated peptide had a molecular weight of $9770 \mathrm{Da}$, was thermostable at $50-90^{\circ} \mathrm{C}$ for $30 \mathrm{~min}$, and tolerated a pH range of $5-7$ at $4{ }^{\circ} \mathrm{C}$ and $25^{\circ} \mathrm{C}$ during the first $24 \mathrm{~h}$, making this isolated antibacterial peptides suitable for use in sterilization and thermal processes, which are very important aspect in food production. The isolated antibacterial peptide caused a rapid and steady decline in the number of viable cells from 2 to $2.3 \log$ units of gram-negative strains and from 1.5 to $1.8 \log$ units of gram-positive strains during $24 \mathrm{~h}$ of incubation. The isolated antibacterial peptide from Saccharomyces cerevisiae may present a potential biopreservative compound in the food industry exhibiting inhibition activity against gram-negative and gram-positive bacteria.
\end{abstract}

Keywords: Saccharomyces cerevisiae; bioactive peptide; antibacterial; ÄKTA pure

\section{Introduction}

Saccharomyces cerevisiae (typically known as baker's yeast) is a single-cell eukaryote that is often utilized in research. S. cerevisiae has proven to be an ideal organism for research applications especially after releasing its genome sequence was released to the scientific community $[1,2]$. This yeast can be stored, and its genome sequence and translated proteins are similar in action to those of other organisms. Its proteome contains cell cycle and signaling proteins [3]. In the past few years, biologically active peptides have been produced in different sources such as food, plants, animals and microorganisms. Many studies have focused on the production, isolation, and purification of the antimicrobial peptides [4].

Antimicrobial peptides (AMPs) are small oligopeptides (AMPs) that typically contain 10-100 amino acids, with a net positive charge and an amphipathic structure [5]. Antimicrobial peptides 
have a broad spectrum of inhibition activity against microorganisms such as bacteria, molds, yeasts, parasites, and some viruses. Many living organisms such as microorganisms, invertebrates, and other species belonging to the animal and plant kingdoms produce antimicrobial peptides [6]. In addition, bioactive peptides produced during the fermentation process by different microorganisms have been used as antibacterial, antioxidant, antihypertensive, anticancer, and immunomodulatory agents, in addition to containing lipid-reducing properties [7]. Several studies have investigated the production of antimicrobial peptides from lactic acid, however, few studies focus on the production of antimicrobial peptides from yeasts in a medium $[7,8]$.

In previous studies, metabolic compounds of Saccharomyces boulardii were separated and examined against 26 bacterial isolates in order to study the compounds' antimicrobial activity. The extracted peptide from Saccharomyces boulardii has ben shown to exhibit high inhibition activity toward Bacillus cereus [9].

It has been reported that some S. cerevisiae strains have the ability to produce antimicrobial peptides. Recent studies demonstrated that the isolated S. cerevisiae CCMI 885 produced small peptides $(<10 \mathrm{kDa})$ that exhibit antimicrobial activity against some yeasts such as Hanseniaspora guilliermondii, Torulaspora delbrueckii, Kluyveromyces marxianus, and Lachancea thermotolerans [10]. The ultrafiltration process with a $10 \mathrm{kDa}$ cut-off was used to extract the antimicrobial peptide from Candida intermedia after growth on YPD agar at $28^{\circ} \mathrm{C}$ over 7 days. The molecular weight of the peptide was $5 \mathrm{kDa}$ exhibiting an inhibition activity against Brettanomyces bruxellensis [11].

Several authors have noted alternate strategies for biocontrol, such as the use of peptide-based killer toxins. For example, Saccharomyces cerevisiae produces peptide-based killer toxins that are able to inhibit the growth of different species of bacteria [12]. Similar results were reported for bioactive peptide production by S. cerevisiae CCMI 885 at $30^{\circ} \mathrm{C}$ for $48 \mathrm{~h}$. These peptides were used to inhibit the growth of some wine-related yeasts [8]. Past research including both in vitro and in vivo studies indicated that Saccharomyces cerevisiae inhibited intestinal tract infections from Bacillus subtilis, B. cereus, Escherichia. coli, Proteus vulgaris, Pseudomonas aeruginosa, Salmonella typhimurium, Salmonella typhi, Staphylococcus aureus, Yersinia enterocolitica, and some yeasts such as Candida albicans [13].

Saccharomyces cerevisiae yeast exhibits antibacterial activity against E. coli, Pseudomonas sp. Salmonella sp., Staphylococcus aureus, and Vibrio cholera. In addition, this yeast strain has antimicrobial activity against other pathogenic bacteria species, yeasts, and molds [14]. Many studies have described the effect of these antimicrobial activities on inhibition zones (zones free of growth).

To date, however, very limited information is available about bioactive peptides from Saccharomyces cerevisiae. Thus, the aim of this study was to investigate the antimicrobial components from a full extract of Saccharomyces cerevisiae, isolate antibacterial peptides, and test their thermostability characteristics which are very important aspect in food production including for sterilization and thermal processes.

\section{Materials and Methods}

\subsection{Microbial Strains}

Saccharomyces cerevisiae ATCC 36858 was obtained from a local scientific store in Basrah, Iraq. Bacillus subtilis ATCC 23857, E. coli ATCC 25922, Klebsiella aerogenes ATCC 13048, and Staphylococcus aureus ATCC 25923 were supplied by the Food Science Department/College of Agriculture/University of Basrah, Iraq and used as indicator strains.

\subsection{Antibacterial Peptide Production}

First, $1 \mathrm{~mL}$ ( $6 \log \mathrm{cfu} / \mathrm{mL}$ ) of activated yeast $(36 \mathrm{~h}$ ) was added to $250 \mathrm{~mL}$ of glucose yeast peptone broth (GTPB) medium (Himedia, Mumbai, India) and incubated at 20, 25, 30, and $35{ }^{\circ} \mathrm{C}$ for 24, 48, 72 , and $96 \mathrm{~h}$, respectively. After incubation, S. cerevisiae cells were removed by centrifugation at $6000 \mathrm{rpm}$ for $20 \mathrm{~min}$ at $4{ }^{\circ} \mathrm{C}$, and the cell free yeast supernatant was filtered with $0.45 \mu \mathrm{m}$ cellulose acetate membranes (Merck company, Watford, UK) [9]. In order to isolate the peptides that were 
released from the yeast in the medium, the filtered metabolic yeast extract was passed through ultrafiltration membranes with pore sizes of $10 \mathrm{kDa}$ (cut-off $10 \mathrm{kDa}$, Millipore and Amicon, USA) and then concentrated (100-fold) with $2 \mathrm{kDa}$ (cut-off $2 \mathrm{kDa}$ ) membranes. The concentrated metabolic yeast extract was lyophilized by freeze-drying (Heto Lab Equipment, Denmark). Next, $100 \mathrm{mg} / \mathrm{mL}$ of lyophilized metabolic yeast was tested against four indicator strains (Bacillus subtilis ATCC 23857, E. coli ATCC 25922, Klebsiella aerogenes, and Staphylococcus aureus ATCC 25923) using the agar well diffusion agar method, and then $100 \mu \mathrm{L}$ of lyophilized peptide was added to the wells $(6 \mathrm{~mm})$ in Nutrient agar (Himedia, Mumbai, India). After incubation, the clear zones were measured in millimeters $[15,16]$.

\subsection{Purification of the Antibacterial Peptide from Yeast}

An ÄKTA Pure 25 System (GE Healthcare Life Sciences, Germany) was used to purify the antibacterial peptides from lyophilized metabolic extracts of S. cerevisiae. The specific column Superdex $200(10 / 300 \mathrm{GL})$ was used with a column volume set at $23.562 \mathrm{~mL}$ and a column diameter set at $10 \mathrm{~mm}$ with a pressure of $1.5 \mathrm{MPa}$. The column was filled with agarose and dextran. A $0.5 \mathrm{M}$ acetate phosphate buffer (pH 5.0) at $0.5 \mathrm{~mL} / \mathrm{min}$ was used for elution, and a $280 \mathrm{~nm}$ UV detector was used to determine the isolated peaks $[17,18]$. Peak fractions were collected, and the antibacterial activity against two indicator strains (E. coli ATCC 25922 and Staphylococcus aureus ATCC 25923) was determined.

\subsection{Characterization of the Antibacterial Peptide}

\subsubsection{Thermal Stability of the Antibacterial Peptide}

To determine the thermal stability of the extracted antibacterial peptide from S. cerevisiae, $5 \mathrm{~mL}$ $(10 \mathrm{mg} / \mathrm{mL})$ of the active peptide was heated at $50,60,70,80,90,100,110$, and $120^{\circ} \mathrm{C}$ for $30 \mathrm{~min}$. The antibacterial activity was estimated by the agar well diffusion agar activity against $E$. coli ATCC 25922 and Staphylococcus aureus ATCC 25923. Next, $100 \mu \mathrm{L}$ of the extracted bioactive peptide was transferred to three wells in a Petri dish containing a Nutrient agar medium. The non-heated bioactive peptide was used as a control sample. The percentage of antibacterial activity was calculated using the following equation:

$$
\text { Inhibitory activity }(\%)=(\mathrm{Ac}-\mathrm{As} / \mathrm{Ac}) \times 100
$$

where Ac is the inhibition zone of control sample, and As is the inhibition zone of test sample.

\subsection{2. $\mathrm{pH}$ Stability of the Antibacterial Peptide}

The lyophilized purified antibacterial peptide from S. cerevisiae was dissolved in distilled water at $10 \mathrm{mg} / \mathrm{mL}$ and adjusted with $1 \mathrm{~N} \mathrm{NaOH}$ or $1 \mathrm{~N} \mathrm{HCl}$ to different $\mathrm{pH}$ values of 2, 3, 4, 5, 6, 7, 8, 9, and 10 . After incubation for $24 \mathrm{~h}$ at $4{ }^{\circ} \mathrm{C}$ and $25^{\circ} \mathrm{C}$, the solutions containing the samples were adjusted to $\mathrm{pH}$ $7.0 \pm 0.02$ with a $0.5 \mathrm{M}$ sodium citrate buffer. The inhibition activity of the peptide was then determined using the agar well diffusion agar method against E. coli ATCC 25922 and Staphylococcus aureus ATCC 25923. After incubation for $24 \mathrm{~h}$ at $37^{\circ} \mathrm{C}$, the percentage of antibacterial activity was calculated [19].

\subsubsection{Molecular Weight of the Antibacterial Peptide}

The molecular weights of the antibacterial peptide extracted from S. cerevisiae were analyzed using sodium dodecyl sulphate with $15 \%$ polyacrylamide gel electrophoresis (SDS-PAGE) as described by Judd [20]. Then, $1 \mathrm{mg} / \mathrm{mL}$ of the antibacterial peptide and standard proteins ( $\alpha$-Lactalbumin 14.4 $\mathrm{kDa}$, Aprotinin $6.5 \mathrm{kDa}$, Glucagon $3.8 \mathrm{kDa}$, and Insulin-A $2.5 \mathrm{kDa}$ ) (Promega Company, Madison, WI, USA) were dissolved in a phosphate buffer and transferred to a vertical slab chamber $(10 \mathrm{~cm} \times 10$ $\mathrm{cm} \times 0.6 \mathrm{~mm}$ ). The gel was run at $50 \mathrm{~mA}$ and $50-70 \mathrm{~V}$ for $3 \mathrm{~h}$. The molecular weight of the extracted antibacterial peptide was determined after the relative mobility $(\mathrm{Rm})$ of the antibacterial peptide and marker proteins were determined per the following equation: 
$\mathrm{Rm}=$ the traveled distance of the peptide or marker proteins/traveled distance of methylene blue dye

\subsection{Mode of Action}

The modes of action (bacteriostatic) of the extracted antibacterial peptide from S. cerevisiae were assayed as described by [10]. The $6 \log \mathrm{cfu} / \mathrm{mL}$ cultures of four indicator strains were cultivated into $100 \mathrm{~mL}$ of Nutrient broth (Himedia, Mumbai, India). The lyophilized purified antibacterial peptide was added to the indicator strain cultures at a final concentration of $0.01 \%(w: v)$. The samples and the control sample (without antibacterial peptide) were incubated at $37^{\circ} \mathrm{C}$. Indicator strain suspensions were taken at 3, 6, 12, 18, and $24 \mathrm{~h}$, and the absorbance was measured by spectrophotometry (Sunny UV.7804C, Tokyo, Japan) at $\mathrm{OD}_{600}$. The viable bacteria cells were determined on the nutrient agar at various incubation periods [12,21].

\subsection{Statistical Analysis}

Statistical analyses of the different treatments cited above were conducted using the SPSS Statistics V22.0 (Statistical Package for Social Sciences, San Antonio, TX, USA). An analysis of the variance (ANOVA table) of the data was conducted and means for treatment values were analyzed $(p \leq 0.05)$ with least significant difference (LSD). Differences were considered significant at $p \leq 0.05$.

\section{Results and Discussion}

\subsection{Optimum Conditions of for Antibacterial Peptides Production}

Both gram-negative bacteria tested including E. coli and Klebsiella aerogenes were inhibited by the presence of the antibacterial peptides produced from Saccharomyces cerevisiae in all the conditions tested (at the four time points and four different temperatures). This was not the case when testing the other two gram-positive bacteria including Bacillus subtilis and Staphylococcus aureus, which better tolerated the presence of the antibacterial peptides produced from Saccharomyces cerevisiae. This could be explained in part by the presence of cell walls comprised of thick layers of peptidoglycan in the case of Gram-positive bacteria. However, Gram-negative bacteria are known to have cell walls with a thin layer of peptidoglycan. The optimum conditions for the production of active peptides from yeast were $25-30{ }^{\circ} \mathrm{C}$ for $48 \mathrm{~h}$, resulting in the highest inhibition towards E. coli and Klebsiella aerogenes. At $20^{\circ} \mathrm{C}$ and $35^{\circ} \mathrm{C}$, the detected antibacterial activity was negligible with no effect against the four indicator strains (Bacillus subtilis, E. coli, Klebsiella aerogenes, and Staphylococcus aureus) especially at 24, 72, and $96 \mathrm{~h}$ (Table 1).

Table 1. The optimum conditions for antibacterial peptides produced from Saccharomyces cerevisiae.

\begin{tabular}{|c|c|c|c|c|c|c|c|c|c|c|c|c|c|c|c|c|}
\hline \multirow{2}{*}{ Strains } & \multicolumn{4}{|c|}{$24 \mathrm{~h}$} & \multicolumn{4}{|c|}{$48 \mathrm{~h}$} & \multicolumn{4}{|c|}{$72 \mathrm{~h}$} & \multicolumn{4}{|c|}{$96 \mathrm{~h}$} \\
\hline & $20^{\circ} \mathrm{C}$ & $25^{\circ} \mathrm{C}$ & $30^{\circ} \mathrm{C}$ & $35^{\circ} \mathrm{C}$ & $20^{\circ} \mathrm{C}$ & $25^{\circ} \mathrm{C}$ & $30^{\circ} \mathrm{C}$ & $35^{\circ} \mathrm{C}$ & $20^{\circ} \mathrm{C}$ & $25^{\circ} \mathrm{C}$ & $30^{\circ} \mathrm{C}$ & $35^{\circ} \mathrm{C}$ & $20^{\circ} \mathrm{C}$ & $25^{\circ} \mathrm{C}$ & $30^{\circ} \mathrm{C}$ & $35^{\circ} \mathrm{C}$ \\
\hline $\begin{array}{c}\text { Bacillus subtilis ATCC } \\
23857\end{array}$ & - & - & + & + & + & + & ++ & ++ & - & - & + & + & - & - & + & - \\
\hline $\begin{array}{l}\text { Escherichia coli ATCC } \\
25922\end{array}$ & + & + & ++ & + & ++ & +++ & +++ & ++ & + & + & ++ & + & + & + & + & - \\
\hline $\begin{array}{l}\text { Klebsiella aerogenes } \\
\text { ATCC } 13048\end{array}$ & + & + & ++ & ++ & ++ & +++ & +++ & +++ & + & ++ & ++ & ++ & + & + & ++ & + \\
\hline $\begin{array}{c}\text { Staphylococcus aureus } \\
\text { ATCC } 25923\end{array}$ & - & - & + & + & + & + & ++ & + & - & - & + & - & - & - & + & - \\
\hline
\end{tabular}

Diameter of inhibition zone $(\mathrm{mm})$ : +++: $16-20 ;++: 12-16 ;+$ : 8-12; -:no inhibitory activity (including the $6 \mathrm{~mm}$ diameter of each well).

\subsection{Purification of the Antibacterial Peptide}

The extracted yeast peptides were passed through super filtration membranes of $10 \mathrm{kDa}$ and 2 $\mathrm{kDa}$ and then freeze-dried. For further purification of the antibacterial peptide fractions, an ÄKTA purifier system was employed. Three peaks appeared after the ÄKTA Pure treatment. Fractions of 21-22 mL (peak 2) and 23-25 mL (peak 3) did not show growth inhibition activity against the two 
tested bacterial strains, while fractions of $16-20 \mathrm{~mL}$ (peak 1) showed the highest growth inhibition (Figure 1). The yield of the antibacterial peptide was $155 \mathrm{mg} / 100 \mathrm{~mL}$ of the culture medium. The inhibition zones were 24 and $20 \mathrm{~mm}$ for E. coli ATCC 25922 and Staphylococcus aureus ATCC 25923, respectively. Gram-negative bacteria (E. coli) appeared to be more sensitive to antibacterial peptide fractions than gram-positive (S. aureus) bacteria. These results were in agreement with Fakruddin et al. [13] who reported that Gram-negative bacteria were more sensitive to yeast peptides when compared to gram-positive bacteria. The inhibition activity of peptides increased proportionally with the $\alpha$-helix of hydrophobic C-terminal peptides. This feature may be related to the composition of the amphipathic amino acids that are necessary for binding the bacterial cell membranes $[19,22]$.



Figure 1. Chromatogram of gel filtration for antibacterial peptides from Saccharomyces cerevisiae by ÄKTA Pure 25 using Superdex 200 10/300 GL. (A) Inhibition zones of E. coli by peak1, (B) non-inhibition zone of E. coli by peak2 and peak3.

\subsection{Characterization of the Antibacterial Peptide}

\subsubsection{Thermal Stability of the Antibacterial Peptide}

The effect of temperature on the S. cerevisiae antibacterial peptide was determined (Figure 2). The results showed that the antibacterial peptide from yeast was stable at different temperatures ranging from 50 to $90^{\circ} \mathrm{C}$ during $30 \mathrm{~min}$ of treatment. Interestingly, an antibacterial activity of $93 \%$ and $95 \%$ for E. coli and S. aureus was sustained even at $100{ }^{\circ} \mathrm{C}$ during $30 \mathrm{~min}$ of treatment. After $120^{\circ} \mathrm{C}$ for $30 \mathrm{~min}$, the antibacterial activity of the peptide was $68 \%$ and $77 \%$ for E. coli and S. aureus, respectively. This thermostable property makes this antibacterial peptide suitable for use in sterilization and thermal processes. The thermal stability of this small peptide could be related to the nature and chemical structures of such peptides, including the primary protein's structure and with low molecular weight. 
Similar reports have shown that antibacterial peptides isolated from different microbial sources are able to persist at high temperatures without any change in the antimicrobial activity $[23,24]$.



Figure 2. The thermal stability of the antibacterial peptide production from Saccharomyces cerevisiae.

\subsubsection{Effect of $\mathrm{pH}$ on the Antibacterial Peptide}

In order to address the $\mathrm{pH}$ properties including dependent and independent effects, the above fragments were estimated for antibacterial activity inhibition against two indicator strains; E. coli ATCC 25922 and Staphylococcus aureus ATCC 25923. The effects of the $\mathrm{pH}$ values on the stability of the antibacterial peptide from S. cerevisiae are shown in Figure 3. An evaluation of the $\mathrm{pH}$ value stability revealed that the antibacterial peptide remained stable after $24 \mathrm{~h}$ at $4{ }^{\circ} \mathrm{C}$ and $25^{\circ} \mathrm{C}$ at $\mathrm{pH}$ values ranging from 4.0 to 7.0 .

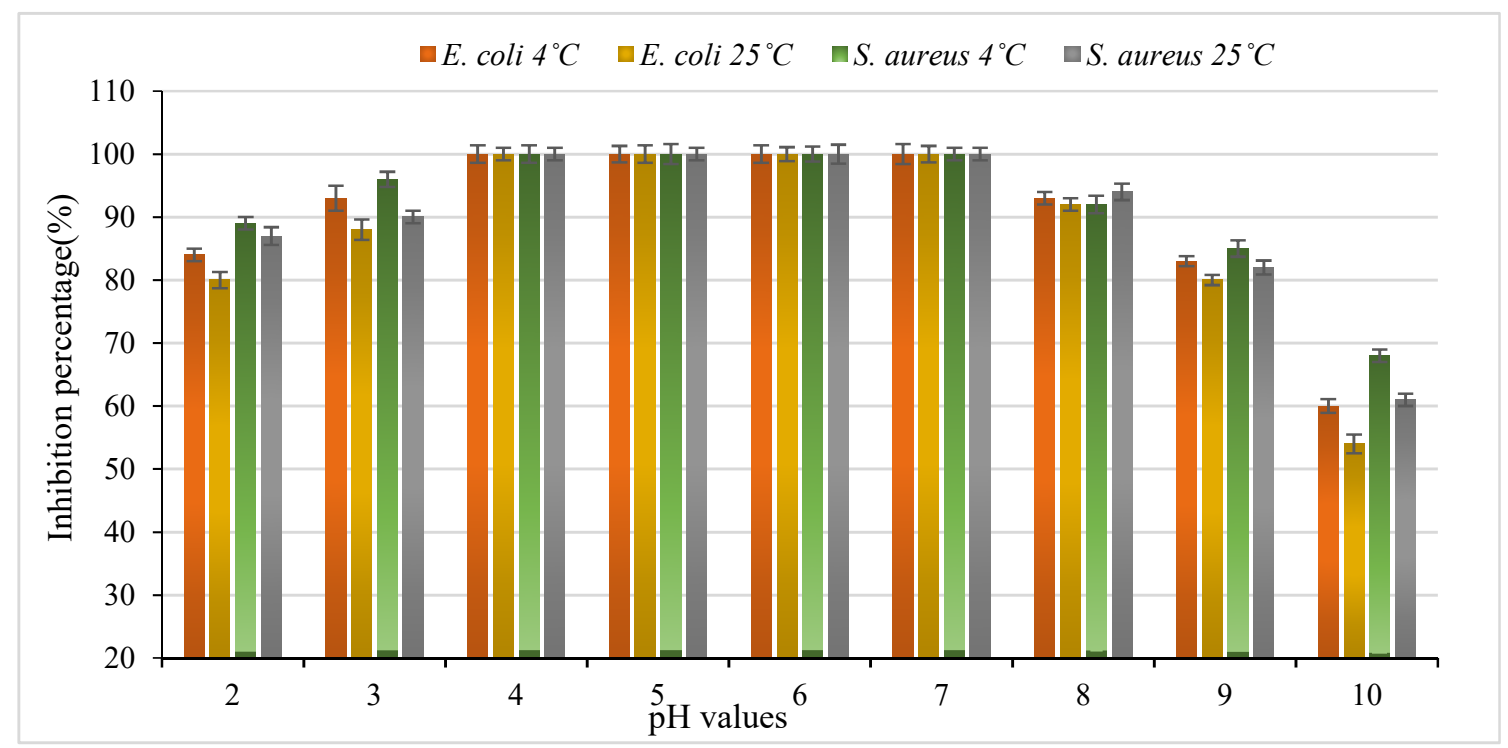

Figure 3. Stability of antibacterial peptide production from Saccharomyces cerevisiae under different $\mathrm{pH}$ and temperature conditions.

The inhibition activity of the peptide with extreme $\mathrm{pH}$ values 2, 3, 8, 9, and 10 against bacterial strains was also tested (Figure 3). Similar properties were previously studied for active peptides 
produced from yeasts, which were easily inactivated by strong acidic and alkaline conditions in different media. These characteristics limit the usage of peptides in food production with acidic and alkaline food. The antibacterial activity of this peptide was evaluated at different $\mathrm{pH}$ values at two temperatures $\left(4^{\circ} \mathrm{C}\right.$ and $25^{\circ} \mathrm{C}$ ). The produced peptide was more effective at $4{ }^{\circ} \mathrm{C}$ within a $\mathrm{pH}$ range from 4 to 7 against the bacterial strains tested when compared to $25^{\circ} \mathrm{C}$. There was no significant difference ( $\mathrm{p}>0.05$ ) between samples of $S$. aureus when tested at $4{ }^{\circ} \mathrm{C}$ and $25^{\circ} \mathrm{C}$ at $\mathrm{pH}$ value 2 , while there was a significant difference $(p<0.05)$ between samples of $E$. coli tested under the same conditions. In contrast, a significant difference $(p<0.05)$ between samples of $S$. aureus and $E$. coli tested at $4{ }^{\circ} \mathrm{C}$ and $25^{\circ} \mathrm{C}$ at a $\mathrm{pH}$ value of 2 was observed. Furthermore, the analysis showed the presence of significant differences $(p<0.05)$ between samples of $S$. aureus tested at $4{ }^{\circ} \mathrm{C}$ and $25^{\circ} \mathrm{C}$ at $\mathrm{pH}$ value 3 . We also observed a significant difference $(p<0.05)$ between samples of $E$. coli when tested at $4{ }^{\circ} \mathrm{C}$ and $25^{\circ} \mathrm{C}$ at $\mathrm{pH}$ 3. When comparing the two bacterial strains, we observed the absence of any significant difference $(p>0.05)$ between samples of $S$. aureus and $E$. coli tested at $4^{\circ} \mathrm{C}$ and $\mathrm{pH} 3$. The presence of significant differences $(p<0.05)$ between samples of $S$. aureus tested at $4^{\circ} \mathrm{C}$ at $\mathrm{pH} 10$ were also observed. However, no significant differences $(p>0.05)$ between samples of $S$. aureus tested at $25^{\circ} \mathrm{C}$ and E. coli tested at 4 ${ }^{\circ} \mathrm{C}$ at $\mathrm{pH}$ value of 10 were observed. Interestingly, the lowest inhibition (\%) value was observed in $E$. coli when tested at $25^{\circ} \mathrm{C}$ and at $\mathrm{pH} 10$.

Overall, the newly discovered produced peptide possessed high thermal stability and a wide range of $\mathrm{pH}$ stability when compared to other peptides produced from microorganisms (e.g., bacteriocins) as described in previous studies $[25,26]$. Moreover, antibacterial peptides acting in neutral and acidic environments are expected to provide protection from many unacceptable microorganisms that grow in these environments, contaminating food and causing spoilage [27].

\subsubsection{Molecular Weight of the Peptide}

The purified antibacterial peptide from active fractions (peak1) was analyzed using SDS-PAGE and showed a single band. The molecular weight of the antibacterial peptide, as determined by relative mobility, was approximately $9770 \mathrm{Da}$ (Figure 4), which is similar to the small molecular weight of other isolated peptides from Klebsiella pneumonia, as described in previous studies [28]. Thus, our results strongly suggest that peak 1 (9770Da) correspond to this peptide and might match the antibacterial activity produced by $S$. cerevisiae and thus be responsible for the bioactive activity shown against the different bacterial strains tested. In this sense, to better understand the role of molecular weight distribution in the inhibition of antibacterial activity of brewer's yeast, a fraction analysis using ultrafiltration with $10 \mathrm{kDa}$ cutoff membranes was performed. The results showed that 3-10 $\mathrm{kDa}$ fractions were fundamentally comprised of smaller peptides with biological activity, which is in agreement with past studies that indicated that antibacterial peptides are small peptides [9].

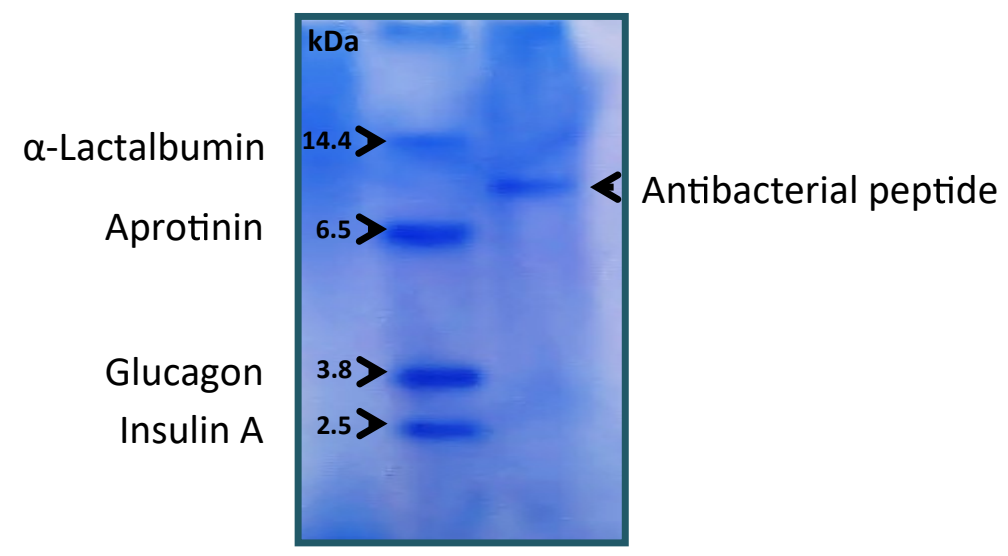

(A)

Figure 4. Cont. 


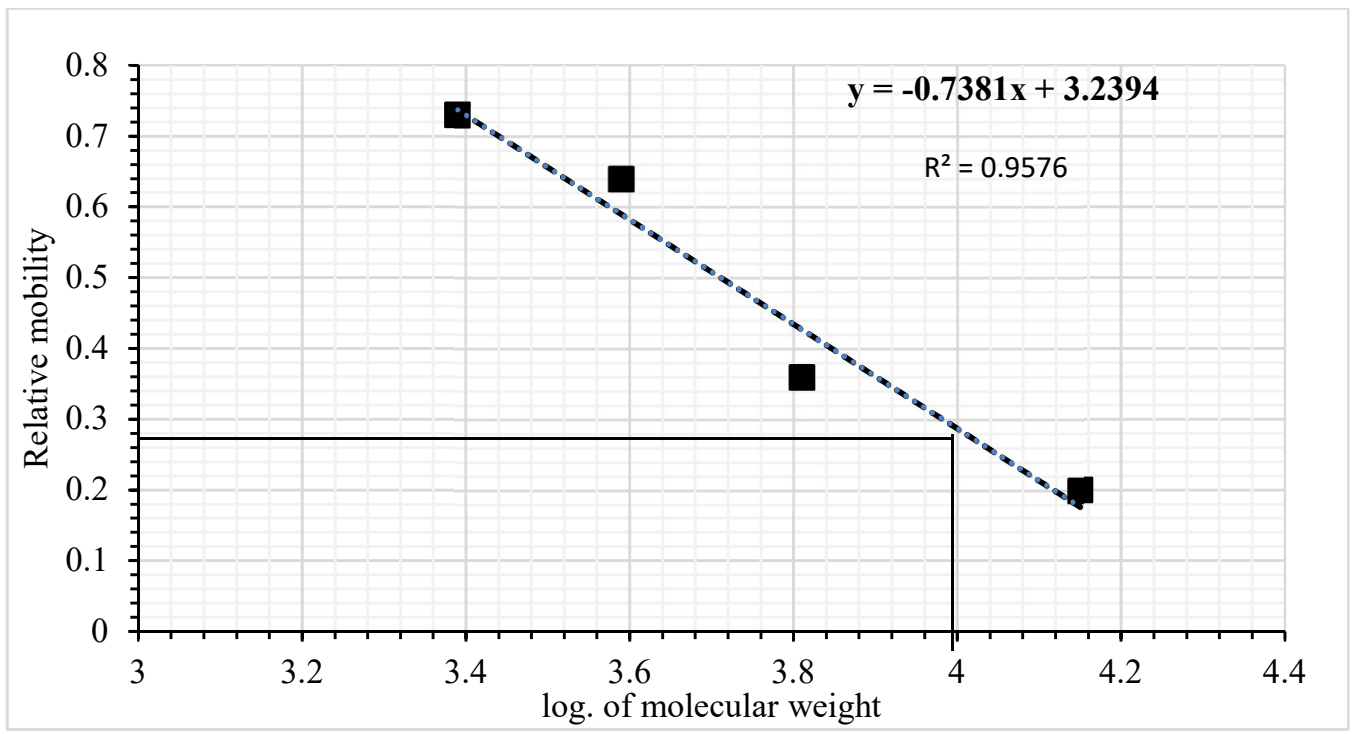

(B)

Figure 4. The molecular weight of antibacterial peptide production from Saccharomyces cerevisiae was determined by electrophoresis method. (A) Sodium dodecylsulfate polyacrylamide gel electrophoresis of standard proteins and the antibacterial peptide. (B) Relative mobility of standard proteins and the antibacterial peptide.

\subsection{Mode of Action}

The antibacterial peptide effect of $S$. cerevisiae on cell viability (kill time) from four indicator strains is shown in Figure 5. The antibacterial peptide reduced the viability of target bacteria compared to the control sample. The antibacterial peptide's efficacy depended on both the concentration of added peptide and exposure time. Additionally, the movement of small peptide and their spread during agar well diffusion appeared $3 \mathrm{~h}$ following the addition of the antibacterial peptide with 5.8, $5.5,5.6$, and $5.8 \log (\mathrm{cfu} / \mathrm{mL})$ reduction of B. subtilis, E. coli, K. aerogenes, and S. aureus, respectively. The statistical analysis of $\log (\mathrm{cfu} / \mathrm{mL})$ reduction for each bacteria strain was estimated at interval times of $3,6,12,18$, and $24 \mathrm{~h}$. The result showed that the antibacterial peptide effect on decreasing the viable cell counts was significant $(p<0.05)$ between the control samples and all four bacterial strains among the five interval times tested. In contrast, there was no significant difference $(p>0.05)$ between either Gram-positive strains or Gram-negative strains. In addition, the peptide's inhibition effect on Gram-negative strains was highly significant $(p>0.05)$ when compared with Gram-positive strains. After $24 \mathrm{~h}$ of incubation, the peptide's inhibition effect on Gram-negative strains was high compared with that of Gram-positive strains. The antibacterial peptide caused a decrease in the viable cell counts of gram-negative strains ranging from 2 to $2.3 \mathrm{log}$. units along the evaluated times in comparison to gram-positive strains which ranged from 1.5 to $1.8 \mathrm{log}$. units. The kill-time of this peptide was in agreement with that from earlier reports $[29,30]$. The mode of action of antimicrobial peptides fundamentally depends on the reaction of bioactive peptides with the membrane of bacteria cells and the cells' internal composition [31]. Generally, the antimicrobial peptides were effective due to the electrostatic reaction with the cell membranes. In order to understand the mechanism behind antimicrobial peptides, the results of various methods have suggested that adsorption of bioactive peptides will occur on the bacterial cell membrane, leading to complete damage to the membrane. For example, the brave straw model, aggregate model, carpet model, and toroid pore model are critically considered models of bioactive peptides as antibacterial compounds [27,32]. 




Figure 5. The mode of action of the antibacterial peptide from Saccharomyces cerevisiae against the four indicator bacteria strains.

\section{Conclusions}

S. cerevisiae belongs to the eukaryotic kingdom is nonpathogenic, and due to its long history of use in the production of consumable products such as ethanol, many baked products, and pastries, it has been classified as a generally regarded as safe organism (GRAS). In this study, antibacterial peptide was produced and isolated from Saccharomyces cerevisiae (Baker's yeast) by an ultrafiltration process (two membranes with cut-offs 2 and $10 \mathrm{kDa}$ ) and purified using the ÄKTA Pure 25 system. The antibacterial peptide activity was then characterized and studied against four bacterial strains. The results showed that the peptide produced by Saccharomyces cerevisiae had a molecular weight of $9.77 \mathrm{kDa}$ and exerted inhibition activity against both Gram-negative and Gram-positive bacteria. The produced peptide was more effective at $4{ }^{\circ} \mathrm{C}$ within a $\mathrm{pH}$ range of 4-7 against the bacterial strains tested when compared to $25^{\circ} \mathrm{C}$, while the lowest inhibition (\%) was observed in E. coli when tested at $25^{\circ} \mathrm{C}$ and at a $\mathrm{pH}$ value of 10 . In addition, the peptide was thermostable and steady with $\mathrm{pH}$ values ranging from $4-7$, which is a very important aspect in food production for sterilization and thermal processes. The isolated antibacterial peptide demonstrated its potential as a bio-preservative in food manufacturing. Although the current study isolated a peptide containing a novel bioactive compound from Saccharomyces cerevisiae, additional research regarding the amino acid sequence and structure of this antibacterial peptide is warranted.

Author Contributions: Investigation, S.T.G.A.-s.; designing and planning the experiments, A.B.A.; Supervision, A.J.A.A.-M.; Methodology, A.K.N.; Writing-review \& editing, N.L.; Writing original draft, S.A.I. All authors have read and agreed to the published version of the manuscript.

Funding: This research received no external funding.

Conflicts of Interest: The authors declare no conflicts of interest.

\section{References}

1. Gordon, J.L.; Byrne, K.P.; Wolfe, K.H. Additions, losses, and rearrangements on the evolutionary route from a reconstructed ancestor to the modern Saccharomyces cerevisiae genome. PLoS Genet. 2009, 5, e1000485. [CrossRef] [PubMed] 
2. Reis, V.R.; Bassi, A.P.G.; da Silva, J.C.G.; Ceccato-Antonini, S.R. Characteristics of Saccharomyces cerevisiae yeasts exhibiting rough colonies and pseudohyphal morphology with respect to alcoholic fermentation. Braz. J. Microbiol. 2013, 44, 1121-1131. [CrossRef] [PubMed]

3. Walker, L.J.; Aldhous, M.C.; Drummond, H.E.; Smith, B.R.K.; Nimmo, E.R.; Arnott, I.D.R.; Satsangi, J. Anti-Saccharomyces cerevisiae antibodies (ASCA) in Crohn's disease are associated with disease severity but not NOD2/CARD15 mutations. Clin. Exp. Immunol. 2004, 135, 490-496. [CrossRef]

4. Hatoum, R.I.M.A.; Labrie, S.T.E.V.E.; Fliss, I.S.M.A.I.L. Antimicrobial and probiotic properties of yeasts: From fundamental to novel applications. Front. Microbiol. 2012, 3, 421. [CrossRef] [PubMed]

5. Offret, C.; Fliss, I.; Bazinet, L.; Marette, A.; Beaulieu, L. Identification of a novel antibacterial peptide from atlantic m13. ackerel belonging to the gapdh-related antimicrobial family and its in vitro digestibility. Mar. Drugs 2019, 17, 413. [CrossRef]

6. Sang, Y.; Blecha, F. Porcine host defense peptides: Expanding repertoire and functions. Dev. Comp. Immunol. 2009, 33, 334-343. [CrossRef]

7. Elfahri, K.R.; Vasiljevic, T.; Yeager, T.; Donkor, O.N. Anti-colon cancer and antioxidant activities of bovine skim milk fermented by selected Lactobacillus helveticus strains. J. Dairy Sci. 2016, 99, 31-40. [CrossRef]

8. Rai, A.K.; Jeyaram, K. Health benefits of functional proteins in fermented foods. In Health Benefits of Fermented Foods and Beverages; Tamang, J.P., Ed.; CRC Press: Boca Raton, FL, USA, 2015; pp. 455-474.

9. Naimah, A.K.; Al-Manhel, A.J.A.; Al-Shawi, M.J. Isolation, purification and characterization of antimicrobial peptides produced from Saccharomyces boulardii. Int. J. Pept. Res. Ther. 2018, 24, 455-461. [CrossRef]

10. Albergaria, H.; Francisco, D.; Gori, K.; Arneborg, N.; Gírio, F. Saccharomyces cerevisiae CCMI 885 secretes peptides that inhibit the growth of some non-Saccharomyces wine-related strains. Appl. Microb. Biotech. 2010, 86, 965-972. [CrossRef]

11. Peña, R.; Ganga, M.A. Novel antimicrobial peptides produced by Candida intermedia LAMAP1790 active against the wine-spoilage yeast Brettanomyces bruxellensis. Antonie van Leeuwenhoek Int. J. Gen. Mol. Microb. 2019, 112, 297-304.

12. Mannazzu, I.; Domizio, P.; Carboni, G.; Zara, S.; Zara, G.; Comitini, F.; Ciani, M. Yeast killer toxins: From ecological significance to application. Crit. Rev. Biotechnol. 2019, 39, 603-617. [CrossRef] [PubMed]

13. Fakruddin, M.; Hossain, M.N.; Ahmed, M.M. Antimicrobial and antioxidant activities of Saccharomyces cerevisiae IFST062013, a potential probiotic. BMC Complement Altern. Med. 2017, 17,1-11. [CrossRef]

14. Rajkowska, K.; Kunicka-Styczyńska, A.; Rygala, A. Probiotic activity of Saccharomyces cerevisiae var. boulardii against human pathogens. Food Technol. Biotechnol. 2012, 50, 230-236.

15. Niamah, A.K.; Al-Manhel, A.J.; Al-Sahlany, S.G. Effect microencapsulation of Saccharomyces boulardii on viability of yeast in vitro and ice cream. Carpathian J. Food Sci. Technol. 2018, 10, 100-107.

16. Altemimi, A.; Lakhssassi, N.; Abu-Ghazaleh, A.; Lightfoot, D.A. Evaluation of the antimicrobial activities of ultrasonicated spinach leaf extracts using rapd markers and electron microscopy. Arch. Microbiol. 2017, 199, 1417-1429. [CrossRef]

17. Jiang, H.; Zou, J.; Cheng, H.; Fang, J.; Huang, G. Purification, Characterization, and Mode of Action of Pentocin JL-1, a novel bacteriocin isolated from Lactobacillus pentosus, against Drug-Resistant Staphylococcus aureus. BioMed. Res. Int. 2017, 7657190. [CrossRef] [PubMed]

18. Wang, Y.; Qin, Y.; Zhang, Y.; Wu, R.; Li, P. Antibacterial mechanism of plantaricin LPL-1, a novel class IIa bacteriocin against Listeria monocytogenes. Food Control 2019, 97, 87-93. [CrossRef]

19. Khani, S.; Seyedjavadi, S.S.; Zare-Zardini, H.; Hosseini, H.M.; Goudarzi, M.; Khatami, S.; Razzaghi-Abyaneh, M. Isolation and functional characterization of an antifungal hydrophilic peptide, Skh-AMP1, derived from Satureja khuzistanica leaves. Phytochemisty 2019, 164, 136-143. [CrossRef]

20. Judd, R.C. Electrophoresis of peptides. In Methods in Molecular Biology; Clifton, N.J., Ed.; Springer's Humana Press: Basel City, Switzerland, 1994; pp. 49-57.

21. Oazi, J.I.; Asif, H.; Shahid, R. Economical method for estimation of bacterial viable count. Pak. J. Zool. 2008, 40, 289-294.

22. Wang, C.; Zhang, Y.; Zhang, W.; Yuan, S.; Ng, T.; Ye, X. Purification of an antifungal peptide from seeds of Brassica oleracea var. gongylodes and investigation of its antifungal activity and mechanism of action. Molecules 2019, 24, 1337. [CrossRef] 
23. Sun, D.; Wu, S.; Jing, C.; Zhang, N.; Liang, D.; Xu, A. Identification, synthesis and characterization of a novel antimicrobial peptide HKPLP derived from Hippocampus kuda Bleeker. J Antibiot. 2012, 65, 117-121. [CrossRef] [PubMed]

24. Zhao, Y.; Zhang, M.; Qiu, S.; Wang, J.; Peng, J.; Zhao, P.; Wang, R. Antimicrobial activity and stability of the d-amino acid substituted derivatives of antimicrobial peptide polybia-MPI. AMB Express 2016, 6, 122. [CrossRef] [PubMed]

25. Moreno, I.; Lerayer, A.L.S.; Baldini, V.L.S.; Leitão, M.F.D.F. Characterization of bacteriocins produced by Lactococcus lactis strains. Braz. J. Microbiol. 2000, 31, 184-192. [CrossRef]

26. Elayaraja, S.; Annamalai, N.; Mayavu, P.; Balasubramanian, T. Production, purification and characterization of bacteriocin from Lactobacillus murinus AU06 and its broad antibacterial spectrum. Asian Pac. J. Trop. Biomed. 2014, 4, S305-S311. [CrossRef]

27. Rai, M.; Pandit, R.; Gaikwad, S.; Kövics, G. Antimicrobial peptides as natural bio-preservative to enhance the shelf-life of food. J. Food Sci. Technol. 2016, 53, 3381-3394. [CrossRef]

28. Thomas, X.; Destoumieux-Garzón, D.; Peduzzi, J.; Afonso, C.; Blond, A.; Birlirakis, N.; Rebuffat, S. Siderophore peptide, a new type of post-translationally modified antibacterial peptide with potent activity. J. Biol. Chem. 2004, 279, 28233-28242. [CrossRef]

29. Branco, P.; Francisco, D.; Chambon, C.; Hébraud, M.; Arneborg, N.; Almeida, M.G.; Albergaria, H. Identification of novel GAPDH-derived antimicrobial peptides secreted by Saccharomyces cerevisiae and involved in wine microbial interactions. Appl. Microb. Biotech. 2014, 98, 843-853. [CrossRef]

30. Comitini, F.; Ferretti, R.; Clementi, F.; Mannazzu, I.; Ciani, M. Interactions between Saccharomyces cerevisiae and malolactic bacteria: Preliminary characterization of a yeast proteinaceous compound(s) active against Oenococcus oeni. J. Appl. Microbiol. 2005, 99, 105-111. [CrossRef]

31. Hasan, M.; Moghal, M.M.R.; Saha, S.K.; Yamazaki, M. The role of membrane tension in the action of antimicrobial peptides and cell-penetrating peptides in biomembranes. Biophysical Rev. 2019, 11, 431-448. [CrossRef]

32. Losasso, V.; Hsiao, Y.W.; Martelli, F.; Winn, M.D.; Crain, J. Modulation of antimicrobial peptide potency in stressed lipid bilayers. Phys. Rev. Lett. 2019, 122, 208103. [CrossRef] 